
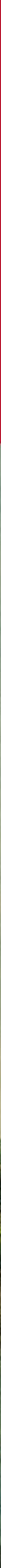


\section{Jakub Rogulski}

\section{The Potockis: the rise of a noble family in sixteenth-century Poland}

Marian Wolski, The Potocki family of the Pilawa coat of arms. A study of Family of history and estates until the early $17^{\text {th }}$ century (Kraków: Towarzystwo Naukowe 'Societas Vistulana', 2017, 452 p., 10 maps)

The equality before the law made the nobility of the Polish-Lithuanian Commonwealth exceptional among the social elites of early modern Europe. In Poland-Lithuania all nobles were formally peers to each other and enjoyed the same rights and privileges (including the rights to vote and select candidates for the throne). Hereditary ranks, apart from a few exceptions, were strictly banned by the Diet of the Polish Commonwealth (Sejm). But this formal legal equality was complicated by differences in real power and wealth, and hence by no means meant actual equality. On the contrary, from this point of view, the Polish-Lithuanian nobility seems to have been highly diversified, much more so than its counterparts in other European countries. The noble estate of the Commonwealth included all who prided themselves on noble birth: both powerful magnates holding high senatorial offices and ruling vast estates as well as the 'naked nobility' (gołota), who did not possess even a small piece of land. Over time, differences in power and property grew in significance, especially after the mid-seventeenth century when due to economic crisis and war damage a small group of families accumulated huge fortunes. The Potockis of the Pilawa coat of arms was one of those powerful magnate houses. (As a distinctive feature of the Polish-Lithuanian nobility, coats of arms were symbols not of separate families but of noble clans that had crystallized as early as the medieval period. Accordingly, the 'Pilawa Coat of Arms' refers both to the very emblem Pilawa as well as to the whole clan encompassing all families using this badge.) In the seventeenth and eighteenth centuries, the Potockis influenced the domestic and foreign pol- 


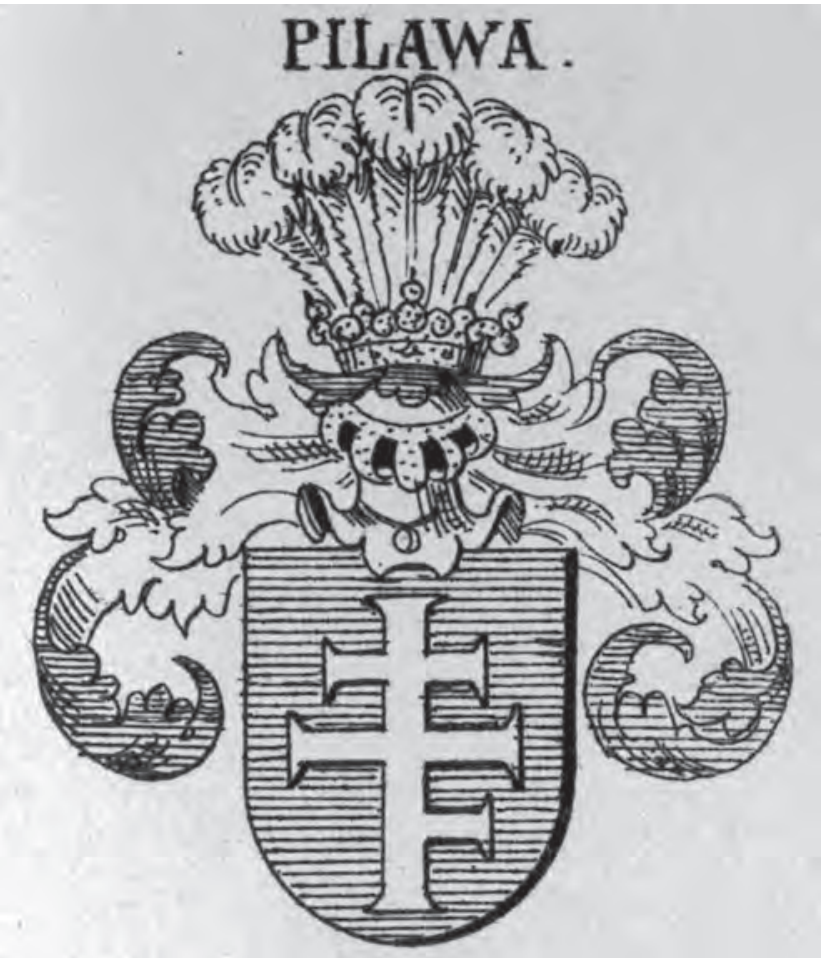

The Pilawa coat of arms

depicted in: Ivan von

Bojničič ed., J. Siebmacher's

grosses und allgemeines

Wappenbuch, 4. Bandes, 14. Abteilung, Adel von

Galizien, Lodomerien u. der Bukowina [Galizisch-Bukowinisches Wappenbuch] (Nürnberg, 1905)

icies of the Polish-Lithuanian Commonwealth so decisively that they are now considered to have been one of the most prominent families in the history of Poland.

Marian Wolski's book, however, does not deal with this period of the family history, as its timeframe ends in the seventeenth century. Indeed, Wolski's interest lies exclusively in the earliest family history. There are two reasons which made this decision both reasonable and fortunate. Firstly, the beginning of the Potocki family's career has been an almost unexplored field, because the political climate of the twentieth century was unfavourable to studies on the nobility in Poland. At the time of the communist regime, for example, these issues were not only thematically unwelcome, but also hard to research as many crucial records were kept in the former Commonwealth (in Ukraine, Belarus, Lithuania and Russia) and were hardly available under the Soviet Union. Only the last decades have made it possible to enhance the knowledge of the history and culture of the early modern nobility. In fact, there has been a recent increase of publications, as evidenced by the book at hand, which was first published in Polish in 2013 (Potoccy herbu Pilawa do poczqtku XVII wieku. Studium genealogiczno-własnościowe, Towarzystwo Naukowe 'Societas Vistulana', 2013). This English edition presents an updated version of the original work.

Secondly, the earliest period of the history of the Potockis provides an illustrative case, which can help us to understand the transformation of the Polish-Lithuanian elites at the dawn of the early modern era. The Potockis originated from a poor family background, and 
initially lived in one of the central regions of the Kingdom of Poland (the Palatinate of Sandomierz). At the beginning of the sixteenth century they still possessed only a small part of their native estate in the village of Potok, from which they took their family name. Yet it took them only three generations to gather significant fortunes in the southeastern borderlands of the Polish-Lithuanian Commonwealth (especially in Red Ruthenia and Podolia) and reach the top of the social hierarchy. The social advancement of the Potockis was impressive, but not exceptional. Throughout the sixteenth century, the old Polish elites who had already acquired rank and fortune in the Middle Ages, successively died out or went into decline. Their place was seized by families from the lower classes who were determined to move upwards by grasping the opportunities brought by the new epoch and the integration of Poland and Lithuania. The Potockis were one of the families who rapidly evolved into the fullfledged magnateria of early modern Polish-Lithuanian state.

Marian Wolski employs two approaches to study the history of this renowned family: a biographical and a generalizing one. Accordingly, the book is divided into two parts. The first one (chapters 4-13) consists of the biographies of the most outstanding family members, starting with Jakub Potocki, the actual progenitor, and ending with his grandsons, who were the first to have brought the family into the Senate, the upper, most prestigious house of the Sejm. Despite being focused on successive 'heads' of the family, Wolski deals with the entire family circle, including Potocki spouses such as Elżbieta Kamieniecka or Maria, daughter of Prince Ieremia Movilă of Moldavia, who significantly contributed to the rise of the family. The second part of the book (chapters 14-15) discusses some general issues concerning the family's history: family relations, estates and finances. The book also includes introductory chapters (1-3), a bibliography, lists of abbreviations, illustrations and maps as well as indexes of names and places at the end. The book furthermore contains ten maps indicating the location of the family estates.

Marian Wolski performs these genealogical tasks in an admirable way. Not surprisingly, he is an experienced and acclaimed specialist of Polish knights and nobles in the Middle Ages and the early modern era (his previous genealogical book, on the Trzecieski family of the Strzemię Coat of Arms, met with a very good reception). Based on extensive sources, gathered during careful research in Poland and abroad (Lviv, Kiev, Moscow and Basel), Wolski refutes some of the claims which have surrounded the earliest family history for centuries, especially those anecdotes embellishing it with heroic or panegyric motives. Instead, he puts forward well-founded hypotheses regarding the origin of the Potockis in the Pampicki family of the Róża Coat of Arms and the adoption of the Pilawa Coat of Arms, a result of the cooperation of the progenitor Jakub Potocki with his patron, Field Hetman Jan Tworowski. Wolski thoroughly discusses the lives, material situations and public activities of all the members of the Potocki family up to the early seventeenth century.

The thorough genealogical investigation provides Marian Wolski with a strong basis for more generalized statements in the second part of his book. While discussing family relations, estates and finances, he tries to show what was decisive for such a quick career as that of the Potocki family. He points at a combination of many factors. Firstly, the Potockis succeeded in choosing powerful patrons (it suffices to mention the famous and influential Field Hetman Tworowski) who effectively promoted them for higher offices and royal favours. 
Furthermore, the family proved particularly successful in seizing attractively located and profitable Crown estates (królewszczyzny), which played a crucial role in their material advancement (these estates were most easily available in the southeast borderlands, which was why the Potockis' move to Ruthenia was so important). In addition to this, the family members appeared to be typical homines economici - they perfectly understood the free economy, invested in landed estates and towns, and also profited from the trade and the transportation through their lands. The Potocki family history also contains some striking examples of family solidarity: they collaborated with each other harmoniously, took care of the estates of relatives, and did not generate any conflicts - an unusual thing in families consisting of many male heirs to the fortune. Last but not least: their marital policies were marked by absolute pragmatism: only daughters of well-to-do families or sisters of bankrupt landowners were selected as spouses.

The second part of the book reconstructs the huge collective effort through which a well-integrated and ambitious family was able to reach the peak of the social ladder. Nevertheless, the analysis leaves the reader with a somewhat unsatisfied feeling. Wolski focuses only on issues of an economic and familial nature - there is a pronounced absence of the cultural perspective. It should be explained that in the absence of any formal distinctions for powerful families in Poland-Lithuania, it was the general public opinion that largely decided who belonged to the magnateria. This public recognition could be gained by pursuing the patronage of the arts and literature, investments in public buildings and institutions, expensive pastimes and other elements associated with the elite's lifestyle - this is why such kind of activity was so relevant for families aspiring to become part of the elite. The creation of a prestigious genealogy, visually expressed by reputable family symbols, played a similar role. The fact that the Potockis changed their coat of arms at the very beginning of their career offers strong arguments to illustrate this tendency. The family's religiosity is another problem largely uncovered by the study. The Potockis' decision to break away from the Catholic Church and adopt Protestantism in its Calvinist variety, made at the dawn of their career, undoubtedly contributed to the rise of the family. Admittedly, it is a pity that the author did not draw separate attention to these vital and interesting issues, which would have provided the reader of the monograph with a comprehensive perspective of the Potocki family history.

These disadvantages, however, do not change the fact that this book is an important, competent and well-written family monograph. By throwing light on the process of advancement of the Potocki family, it enables the reader to understand the circumstances in which the noble equality principle - something cherished in Poland-Lithuania - diverged so crucially from the actual social structure, becoming in fact nothing but an idealized fiction. The English edition of the book also has an additional merit. As mentioned above, the Polish historiography has recently abounded with publications on the history and culture of the Polish-Lithuanian nobility. Due to the language barrier, all this output is hardly known beyond Poland (and the countries historically related to it). The book by Wolski provides foreign readers with a valuable insight into the early modern social elites of Poland-Lithuania. 
Houses divided? Noble familial and class connections during the Age of Revolution and Napoleon

\section{Mary K. Robinson}

'Le marriage m'a toujours fait peur.' Ongehuwde adellijke vrouwen in de zeventiende en achttiende eeuw

\section{Evelyn Ligtenberg}

Steekpenning of welkomstgeschenk? De strijd voor eerherstel van Gerrit Burchard en Adolf Hendrik van Rechteren

\section{Michel Hoenderboom}

The politics of presence. Place making among the Swedish iron producers in the county of Västmanland ca. 1750-1850

Marie Steinrud

De Belgische orangistische adel, deel II. De rol van de adel in het Belgisch orangisme (1830-1850)

Els Witte 